\title{
Recent advances in food allergy
}

\section{Tópicos recentes em alergia alimentar}

\author{
Marcos Julio Caruso Alcocer ${ }^{1 *}$, Silvia de la Cruz Ares ${ }^{2}$, Inés López-Calleja ${ }^{2}$ \\ ${ }^{1}$ University of Nottingham, School of Biosciences, Sutton Bonington, United Kingdom \\ 2Universidad Complutense de Madrid, Facultad de Veterinaria, Departamento de Nutrición, Bromatología y Tecnología de los Alimentos, Madrid, Spain
}

\section{${ }^{*}$ Corresponding Author}

Marcos Alcocer, University of Nottingham, School of Biosciences, LE12 5RD, Sutton Bonington, United Kingdom, e-mail: Marcos.alcocer@nottingham.ac.uk

Cite as: Recent advances in food allergy. Braz. J. Food Technol., v. 19, e2016047, 2016.

Received: Apr. 19, 2016; Accepted: July 07, 2016

\section{Summary}

Food allergy is a public health issue that has significantly increased worldwide in the past decade, affecting consumers' quality of life and making increasing demands on health service resources. Despite recent advances in many areas of diagnosis and treatment, our general knowledge of the basic mechanisms of the disease remain limited i.e., not at pace with the exponential number of new cases and the explosion of new technologies. Many important key questions remain: What defines a major allergen? Why do some individuals develop food allergies and others do not? Which are the environmental factors? Could the environmental factors be monitored through epigenetics or modified by changes in the microbiome? Can tolerance to food be induced? Why are some foods more likely to trigger allergies than others? Does the route and timing of exposure have any role on sensitization? These and many other related questions remain unanswered. In this short review some of these topics are addressed in the light of recent advances in the area.

Keywords: Food allergy; Allergens; Tolerance; Sensitization; Treatment.

\section{Resumo}

A alergia alimentar é uma questão de saúde pública que tem aumentado significativamente na última década em todo o mundo, afetando a qualidade de vida dos consumidores e fazendo demandas crescentes sobre os recursos dos serviços de saúde. Apesar dos recentes avanços em muitas áreas de diagnóstico e tratamento, o nosso conhecimento geral dos mecanismos básicos da doença permanecem limitados, isto é, não avança no mesmo ritmo exponencial de novos casos e chegada de novas tecnologias. Muitas questões importantes permanecem: O que define um alérgeno principal? Por que algumas pessoas desenvolvem alergias alimentares e outras não? Quais são os fatores ambientais? Poderiam os fatores ambientais serem monitorados através de técnicas epigenéticas ou modificados por mudanças no microbioma? Poderia tolerância ao alimento ser induzida? Por que alguns alimentos são mais propensos a desencadear alergias do que outros? Será que a rota e tempo de exposição têm qualquer papel na sensibilização? Estas e muitas outras questões relacionadas permanecem sem resposta. Nesta breve revisão, alguns destes tópicos são abordados à luz dos recentes avanços na área.

Palavras-chave: Alergia alimentar; Alérgenos; Tolerância; Sensitização; Tratamento.

\section{Introduction}

Food allergy is a public health issue that has significantly increased worldwide in the past decade, affecting consumers' quality of life and making increasing demands on health service resources (CIANFERONI; SPERGEL, 2009; LIEBERMAN; SICHERER, 2010, BURKS et al., 2012). According to EAACI reports, approximately 17 million people in Europe are suffering from food-related allergies and critical hospital admission for children has increased by 7 -fold within the past 10 years.
Food allergy affects around $2-4 \%$ of the population peaking at $6-8 \%$ at 1 year of age and declining gradually to $2-4 \%$ in older children and adults (RONA et al., 2007; ZUIDMEER et al., 2008, MADSEN et al., 2009). This decline reflects the fact that many infants grow out of their food allergies as they age. The rate and probability of resolution varies significantly between specific foods. Frequently, egg, milk, wheat and soy allergies resolve relatively early in life, whereas allergies to 
peanuts, tree nuts, sesame seeds, fish, crustacean shellfish and buckwheat tend to persist. However it remains unclear why some children or adults achieve natural tolerance and others do not. Interestingly, several studies indicate that $75 \%$ of allergic reactions among children are linked to a limited number of foods, which include egg, peanut, cow's milk, fish and various nuts. Conversely in adults, fruits of the latex group (e.g. kiwi, banana), fruits of the Rosaceae family (e.g. apples, pears, prunes), vegetables of the Apiaceae family (e.g. carrot, celery), and various nuts and peanuts are responsible for $50 \%$ of allergic reactions (KANNY et al., 2001, SASTRE, 2010; DUPONT, 2011; GADERMAIER et al., 2011).

Several analytical approaches have been developed for the detection and quantification of allergens in food products. These techniques target either the allergen itself or a corresponding allergen marker (peptide fragment or gene segment). Due to the diverse nature of food allergens and the complexity of the respective food matrices, the choice of detection methods can be challenging at times. With the recent advances in molecular biology, biochip technology, mathematical modelling amongst others and access to large volume of information on genomics, genomic associated studies, cell culture, cell engineering, microbiome and many of the new omics, the whole diagnostic, therapeutic and basic immunology area of food allergy is undergoing great transformation. This is a major contrast with the accumulated knowledge of the basic mechanisms of the disease. Since the pioneering work in the early 1920s demonstrating the transfer of sensitivity to a non-allergic person and the discovery of IgEs in the 50 s, our general knowledge of the basic mechanisms of the disease has remained limited i.e., not at pace with the exponential number of new cases and the explosion of new technologies. Many important key questions remain: What defines a major allergen? Why do some individuals develop food allergies and others do not? Which are the environmental factors? Could the environmental factors be monitored through epigenetics or modified by changes in the microbiome? Can tolerance to food be induced? Why are some foods more likely to trigger allergies than others? Does the route and timing of exposure have any role on sensitization? These and many other related questions remain unanswered.

In general terms, food allergy can be defined as an immune-mediated sensitivity to food proteins (BOYCE et al., 2010). It is essentially «immunity gone wrong» where normally harmless substances (food allergens) are perceived as a threat and acted upon by the body's immunological defences. In a type I hypersensitivity reaction the adaptive immune system responds by producing IgE antibodies against the allergens. It is a two-step process where the capacity to respond through an allergic reaction when exposed to the particular allergen must be first established.
This induces the immune system to generate specific IgE antibodies against the allergen in a so-called induction phase, or sensitization. Once sensitized to a particular allergen, the individual may develop a symptomatic allergic reaction when exposed again to the allergen in question in a provocation or later triggering phase (SICHERER; SAMPSON, 2010).

Interestingly what defines a major allergen is still largely unknown. More importantly the intrinsic factors that differentiate a common everyday food protein from a fatal allergen to a particular group of patients remain largely unknown. Despite the attempts by a large number of groups to define the basic intrinsic characteristics of an allergenic protein, only 2 mechanisms, both described in the Dermatophagoides pteronyssinus (house dust mite), are currently known: a protease dependent one (Der p 1) and a protease independent one (Der p 2). In the former, Der $\mathrm{p} 1$ protease activity has been shown to cleave CD23, CD25 and CD40, inhibiting IL-12 secretion with the possible activation of the PAR family of $\mathrm{G}$ coupled proteins in the process (KAUFFMAN et al., 2006). In the latter mechanism, it has been elegantly shown that Der $\mathrm{p} 2$ structurally mimics MD2, a component of the TLR4 complex that can co-opt other signalling components to activate its target cells (TROMPETTE et al., 2009). Hence the involvement of complex lipids and Toll receptors has been clearly demonstrated. However, as most of the well-characterised allergens are not proteases and it is unlikely that MD2 homology could be a general mechanism for allergenicity, this suggests that other mechanisms certainly exist.

This means that current understanding of the molecular mechanisms underlying the development of IgE responses is incomplete and as a result any risk assessment regarding allergenicity has to rely on historic evidences. Factors such as the age when the initial sensitization occurred, genetic susceptibility, environmental factors including geographic distribution, exposure route, type of food, food matrixes and adjuvants, amongst many others, should be considered. As a consequence of this complexity decision-tree approaches have been proposed to facilitate allergenicity assessment. The classical International Life Science Institute decision tree of 1996 (ILSI) (METCALFE et al., 1996) and its revised version proposed by a joint FAO/WHO committee (WHO; FAO, 2001) are examples of these. Although no longer followed by many European countries, the essential information contained in these decision-trees i.e. relationships between novel proteins and known allergens, cross-reactivity defined using patient allergic sera, in vitro measures of protein digestibility, in vivo sensitisation using animal models, and bioinformatics data, are still used today as important parameters for the approval of novel food proteins. The criticisms and limitations of the different approaches currently used in 
the assessment of allergenicity are out of the scope of this article, hence alternative methodologies are sought.

\section{Protein arrays}

In the search for alternative methods for allergenicity assessment, protein chip technology has been shown to be a convenient tool for the measurement of specific allergen IgE levels. However, its application in the diagnosis of food allergy has been hampered by at least two basic factors: representativeness and lack of clinical support. With the availability of a great number of genomic sequences and NMR/crystallographic structural studies it is now possible to trace the taxonomy and genetic relationships of a great number of common allergens and their progenitor plant, insect, parasite or animal cells. The newly acquired knowledge adds to our understanding of ordinary cross-reactivities of physiological importance. One interesting outcome from these studies is the shear realization of the dauntingly large number of proteins our body is exposed to daily. Several domesticated crops, for instance, possess a genome size that in many cases is several folds larger than the human genome. Hence the representation by groups of cross-reacting substance or a few hundred biological markers as present in current commercial protein arrays, are orders of magnitude away from the actual representation faced daily by our immune system. Thus despite the heavy investments on the array area trying to demonstrate otherwise the whole representativeness area is very much open to debate. The second factor that restricts the acceptance of the arrays in diagnostics refers to the fact that they only measure the presence of allergen-specific immunoglobulin in vitro, which in most cases does not necessarily correlate with the observed clinical symptoms. Although more biological alternatives such as effector basophilic cells in conjunction with the protein array platform have been suggested as replacements for the skin prick test (LIN et al., 2007) thus far no significant technical progress has been achieved on this system.

\section{Basophils}

Once sensitised, basophils and mast cells are the effector cells in acute allergic reactions to food, including anaphylaxis (SANTOS et al., 2015). With a frequency of less than $1 \%$ of total white blood cells, human peripheral blood basophils are one of the rarest leukocytes. The purification of basophils therefore requires relatively sophisticated, multi-step purification protocols and large volumes of blood, which are time-consuming and expensive. Basophilic cells from peripheral blood are therefore not considered as standard laboratory reagents however, recent advances in the flow-assisted analysis of basophils, also known as the basophil activation test (BAT), have shown high sensitivity and specificity in the detection of traces of functionally active food allergens (SABATO et al., 2014). Moreover, BAT has been shown to be superior to other diagnostic tests in the discrimination between peanut allergic and peanut sensitised individuals, a disputed area in clinical diagnostics (SANTOS et al., 2014).

In order to obtain a more stable in vitro test, humanised rat basophilic leukaemia cells (RBL) have been engineered and used for monitoring specific allergen sensitisation in patient serum. Several humanised RBL cell lines have now been produced containing at least the human $\alpha$ chain of FCERI, as human IgE does not bind to the rodent IgE receptor. $\mathrm{FCERI}_{\mathrm{R}}$ is expressed in human basophilic cells as the heterotetrameric $\alpha \beta \gamma 2$ form (NOVAK et al., 2001). While the $\alpha$ chain is responsible for IgE binding, the $\gamma$ chain is responsible for signal transduction through the cell membrane. The $\beta$ chain is thought to act as an enhancer of both surface expression and signal transduction. During basophilic activation a number of surface activation markers with different kinetics were used as reporters: CD13, CD63, CD107a CD164, CD203c (BUHRING et al., 2004; HENNERSDORF et al., 2005), but the enzymatic release of $\beta$-hexosaminidase during degranulation is mainly used as the end point. A critical issue with these cell lines has been the cytotoxicity of certain human sera for rat cells, requiring high dilutions and resulting in insufficient sensitisation. A complete review on recent developments in RBLs can be found in (FALCONE; GIBBS, 2014; GIBBS; FALCONE, 2014) and their use in allergenicity assessment of food products in (VOGEL et al., 2006).

Recently it has been demonstrated that passive sensitization using the human mast cell (LAD2) reproduced in vitro the clinical reactivity to peanut in vivo (SANTOS et al., 2015). This is an important landmark and opens an important precedent where cumbersome Skin Prick Tests and food challenges can potentially be replaced by in vitro cellular tests. With the availability of new cell lines (dendritic cells, NKT, gut epithelial) and a better understanding of the basic immunological mechanisms behind the sensitisation phase, the once dominated field of protein only allergens is now being challenged. More than ever it is becoming clear that accessory cells and other signals from the food matrix might play important roles in the overall allergenicity (MIROTTI et al., 2013).

\section{Other IL-4 inducing cells}

In recent studies investigating the basic mechanisms responsible for food allergy (CoFAR) it was demonstrated that the IL-4 expression in peripheral blood mononuclear cell (PMBC) was associated with clinical allergy to milk and peanut (CAUBET et al., 2014). Interestingly, by isolating the IL-2 receptor positive cells (CD25+ PBMC) no increase in GATA-3 was observed, suggesting that other non-T cells might be the source of IL-4. NK, NKT and basophils for instance were found in the CD25+ isolated 
cell population. It has been demonstrated that basophils might be important in priming and enhancing memory Th2 responses, and some authors have suggested that the $\mathrm{MHC}$ class II expressing basophils might also play a central role in antigen presentation (CAUBET et al., 2014).

Another strong indication that other cell types might have a significant role in allergenicity comes from the work on food matrixes, lipids and their signalling via NKT. Accumulating evidences demonstrated that large numbers of protein allergens possess a lipid binding site or lipid transfer functions. The presence of the hydrophobic site and the observation that other components co-presented with proteins can influence the initial stages of allergic sensitisation, are therefore of growing interest. It has been reported for instance that the cat allergen Fel d 1 cannot directly activate the immune system, but requires binding to the bacterial endotoxin LPS, which activates TLR4 via the MD2 protein (HERRE et al., 2013). It is also now apparent that non-bacterial components, such as lipids naturally present in pollen and nuts, can also activate the immune system and may play a role in allergic sensitisation. As with MD2 activation, this further suggests a potential involvement of activated innate immune response through endogenous "cargo" or "danger" signals (Toll-like, Dectin, Nod-like receptors) directly affecting the intrinsic allergenicity of lipid binding allergens from insects, nematodes, fungi and plants (GEORAS et al., 2010). This cargo signalling is particularly pronounced in our interaction with pollens for instance as has been well characterised in oral allergy syndromes (OAS). In initial studies, lipids have been profiled from 22 pollens and they demonstrated a wide variation among species, some with immune-stimulatory and other with immune-regulatory effects (BASHIR et al., 2013). In another series of papers the well-described hydrophobic site of Bet $v 1$ was shown to bind a large number of hydrophobic molecules with a large range of biological activities, albeit with low specificity. Additionally, Pollen Associated Lipid Mediators (PALMs) have been isolated from pollen grains, that appear to modulate immune responses promoting a $\mathrm{TH} 2$ response favouring pro-allergic micromillieu in exposed tissues (GILLES et al., 2009, 2010; BECK et al., 2012).

Besides the conventional toll receptors route, lipids may activate the immune system through processing and presentation via Antigen Presenting Cells (APCs) to Natural Killer T cells (NKT). NKT cells are a unique population of innate-like or natural memory $T$ lymphocytes that exhibit the properties of both conventional T cells and NK cells. Once activated, NKT cells can rapidly secrete (within 1-2h) large amounts of Th1 and Th2 cytokines without clonal expansion that will activate various immune cells playing a central role, bridging innate and adaptive immune responses. The majority of NKT cells express highly restricted TCRs with an invariant $\alpha$-chain ( $V \alpha 24-J \alpha 18$ in humans and
V $\alpha 14-J \alpha 18$ in mice) and limited $\beta$-chains, therefore they are referred to as Type I or invariant NKT cells (iNKT) (PEl et al., 2011; RHOST et al., 2012). Type II cells form the remaining NKT cells and express non-invariant TCRs. Most NKTs recognize lipid antigens presented by CD1, a $\mathrm{MHC}$ class I-like antigen-presenting molecule expressed in APCs. Natural ligands for CD1 include a wide range of both self and non-self glycolipids with one of the most potent CD1 ligands $\alpha$-galactosylceramide, isolated from a marine sponge organism. Some pollen lipids have also been recognised via this pathway. Furthermore our group has shown that a natural lipid fraction from Brazil nut provided an essential adjuvant activity for sensitisation to the Brazil nut allergen Ber e 1, and that iNKT cells play a critical role in the development of Brazil nut-allergic response (MIROTTI et al., 2013). This work corroborated earlier work comparing PBMC responses from children with cow's milk allergy (CMA), egg allergy with tolerance of milk, and healthy control subjects. In this work the authors showed that milk sphingomyelin could induce invariant natural killer T-cell activation and Th2 cytokine production (JYONOUCHI et al., 2011). Are the NKTs or other similarly accessory regulatory cells the missing components for the establishment of the intrinsic allergenicity of proteins? It is interesting to note that this mechanism is conserved throughout our co-evolution history with parasites. Not surprisingly some parasites and parasite components have been shown to activate human NKT cells and activate a strong Th2 response that lead to IgE production. Indeed, whereas IgE appears to have evolved as a response to parasitic infestation to provide protection for the affected individual, allergic reactions are considered to be a purely pathologic consequence of the disruption of this immune response. With the development of new cell lines we might soon be able to test these ideas.

\section{Microbiome/epigenetics}

With the recent advances in microbiome and our incremental understanding of gut physiology, the whole area of food tolerance induced by the commensal bacteria and their epigenetic implication as modulators of the immune system is going through a major revolution. Initial animal studies on the effect of food allergy on the gut microbial ecology have demonstrated that disease-associated microbiota may play an important role in food allergy.

Food tolerance is arguably one of the first and most significant challenges that the gut immune system faces. From the sterile environmental of the womb, the newborn is exposed to a large array of new antigenic proteins in relatively high doses. Most of this foreign antigenic load is derived from colonizing commensal bacteria and food components. To prevent inflammatory responses to these largely harmless antigens, the gastrointestinal-associated lymphoid tissue has evolved complex mechanisms to 
promote tolerance as a default response (PRESCOTT; ALLEN, 2011). Dendritic cells (DC) play a central role in the process, producing immunomodulatory cytokines (IL-10 and TGF- $\beta$ ), which suppress local inflammation in an antigen nonspecific manner. DC also promotes differentiation of antigen-specific regulatory T cells (Treg), essential for systemic immune surveillance and tolerance. In other systems it has been demonstrated that dietary factors can modify the heritable risk of allergic airway disease through epigenetic mechanisms during a period of foetal development in mice (HOLLINGSWORTH et al., 2008). Thus it is possible that the increased risk of allergic disease might be a consequence of environmental heritable changes in gene expression in preceding generations (PRESCOTT; ALLEN, 2011). Animal studies have suggested that commensal microbiota might play a critical role in maintaining food tolerance. Food allergy prone mice that presented a mutation in the IL-4 receptor $\alpha$ chain (II4raF709) were subjected to oral sensitization with chicken egg ovalbumin (OVA) and enforced tolerance achieved using allergen-specific regulatory $T$ (Treg) cells. Interestingly the OVA-sensitized II4raF709 mice exhibited a specific microbiota signature characterized by the abundance of taxa of several bacterial families, such as Lachnospiraceae, Lactobacillaceae, Rikenellaceae, and Porphyromonadaceae (RIVAS et al., 2013). Treatment of OVA-sensitized II4raF709 mice with OVA-specific Treg cells led to a distinct tolerance-associated signature coincident with the suppression of the allergic response. Moreover the microbiota of allergen-sensitized II4raF709 mice differentially promoted OVA-specific IgE responses and anaphylaxis when reconstituted in WT germ-free mice (RIVAS et al., 2013). Thus it is possible that alterations in the composition of the microbiota (dysbiosis) disturb the partnership between the microbiota and the human immune system, ultimately leading to inflammatory disorders (ROUND; MAZMANIAN, 2009). Whether these alterations can be achieved by supplementation of pre-(pro) biotics remains to be shown (FORSBERG et al., 2013). Taken together the animal experiments linked to the recent developments on the production and use of T-regs in the treatment of some cancers suggest several interesting novel cellular and molecular pathways for modulation of the immunological responses (FEEHLEY; NAGLER, 2014). The important validation of the transfer of tolerance by microbiota to humans however, remains to be demonstrated.

\section{New challenges and future}

Recent reports from both Australia and the United States suggest that vitamin $\mathrm{D}$ might play a role in the recent increase in food allergy. Using indirect markers of food allergy status the results suggest that the further the patients reside from the equator, i.e. lowest ambient UV radiation, the more likely they will suffer from food allergy. Vitamin D levels are known to be associated with atopic disease development and the association of food allergy with latitude is most likely restricted to IgE-mediated mechanisms (OSBORNE et al., 2012). The existent data however, are controversial. In preliminary studies Vitamin $\mathrm{D}$ deficiency was associated with higher levels of IgE sensitization in children and adolescents (SHARIEF et al., 2011). However later studies demonstrated that high vitamin $\mathrm{D}$ levels in pregnancy and at birth may contribute to a higher risk for food allergy and therefore argues against vitamin $\mathrm{D}$ supplementation to protect against allergy (WEISSE et al., 2013).

Regarding treatment, the last few years have witnessed interesting new ideas on oral, subcutaneous and epicutaneous desensitisation using a plethora of methods such as anti IgE antibodies (omalizumab), herbal therapy, chimeric allergen-lgG, Fce blockage, lymph node injection and patch therapy amongst others (SICHERER; SAMPSON 2014). Some are now in clinical trial phase II, others have just gone through the feasibilities studies. Although interesting and promising, the actual validation of the efficacy in humans still remains to be demonstrated. In the area of tolerance some interesting progress has been reported on the acceleration of the resolution of cows's milk and egg allergy in children, by increasing dietary baked allergen intake (KIM et al., 2011; LEONARD et al., 2012). The results from these controlled studies suggest that simple measures are better than complete avoidance. On the same desensitisation route, the group in Addenbrooke in Cambridge have successfully induced desensitization in children with different degrees of severity to peanut allergy. The peanut Oral Immune therapy (OIT) used was able to raise the reactive threshold to at least 25 times, and in some cases almost $90 \%$ of the participants could tolerate the daily ingestion of up to $800 \mathrm{mg}$ protein (ANAGNOSTOU et al., 2014). A recent development widely discussed in the 2015 EAACl meeting refers to the use of epicutaneous immunotherapy (EPIT). French and American groups have shown that epicutaneous but not oral immunotherapy induced the generation of gastrointestinal-homing antigen-specific Tregs in the skin-draining lymph nodes, which translates into an increased number of Tregs in the gastrointestinal tract. The induction of gastrointestinal Tregs is associated with an enhanced protection of mice from food-induced anaphylaxis by EPIT (TORDESILLAS et al., 2015). Some work, not yet published in humans, has also been discussed. The recent EPIT findings suggest the skin as a potent modulator of the allergic responses. This is interesting as in earlier work (2001-2003) the UK Avon Longitudinal study involving c.a. 14000 families showed there was a possible link between the development of allergy to peanut and the use of creams on the skin to treat eczema. These findings and the recently reported cases of wheat-dependent exercise induced anaphylaxis patients sensitised to hydrolysed wheat protein in facial soap in Japan (HIRAGUN et al., 2013), corroborate the 
skin as a potent modulator of allergic responses. Whether these responses could be exacerbated by the presence of lipids or surfactants and NKT involvement or suppressed by induction of $\mathrm{T}$ regs as in the EPIT system, remain to be demonstrated.

Regarding the timing and selection of specific complementary foods, many studies continue to suggest that prolonged avoidance of solids or specific allergens is not protective and might be a risk factor with regard to atopy or food allergy prevention (SICHERER; SAMPSON, 2014). In this regard one of the most interesting developments regarding the natural induction of tolerance is the recent findings by the Learning Early about Peanut Allergy (LEAP) study (DU TOIT et al., 2015). Peanut allergy develops early in life and as described above it is rarely outgrown. Clinical practice guidelines in the UK and USA recommended the exclusion of allergenic foods from the diets of infants at high risk for allergy and from the diets of their mothers during pregnancy and lactation. However, it was observed that the risk of the development of peanut allergy was 10 times as high among Jewish children in the United Kingdom as it was in Israeli children of similar ancestry. Furthermore it was noticed that in the UK infants do not consume peanut-based foods in their first year of life, whereas in Israel, peanut-based foods are usually introduced in the diet when the infants are approximately 7 months of age. This was the motivation behind the LEAP study aiming to determine whether an early introduction of peanuts would offer protection from developing peanut allergy. The initial findings of the LEAP study were impressive. The early introduction of peanuts significantly decreased the frequency of the development of peanut allergy among high-risk children when compared with peanut avoidance at the age of 60 months (DU TOIT et al., 2015). Although these are still initial results and many aspects of the study such as dosage and low/high risk-patients need to be worked out, this study has been pivotal in altering pre-conceived ideas. From the number of interim guidance and discussions prompted in a number of allergy related societies worldwide, one has an idea of the importance of these findings (FLEISCHER et al., 2015).

\section{Acknowledgements}

López-Calleja and de la Cruz Ares were supported by Ministerio de Economía y Competitividad of Spain (Grant No. AGL 2013-48018-R). Silvia de la Cruz was also the recipient of a fellowship from the Ministerio de Educación, Cultura y Deporte of Spain (AP2010-0028).

\section{References}

ANAGNOSTOU, K.; ISLAM, S.; KING, Y.; FOLEY, L.; PASEA, L.; BOND, S.; PALMER, C.; DEIGHTON, J.; EWAN, P.; CLARK, A. Assessing the efficacy of oral immunotherapy for the desensitisation of peanut allergy in children (STOP II): a phase 2 randomised controlled trial. Lancet, London, v. 383, n. 9925, p. 1297-1304, 2014. http://dx.doi.org/10.1016/S0140-6736(13)62301-6. PMid:24485709.

BASHIR, M. E. H.; LUI, J. H.; PALNIVELU, R.; NACLERIO, R. M.; PREUSS, D. Pollen lipidomics: lipid profiling exposes a notable diversity in 22 allergenic pollen and potential biomarkers of the allergic immune response. PLoS One, San Francisco, v. 8, n. 2, p. e57566, 2013. http://dx.doi.org/10.1371/journal.pone.0057566. PMid:23469025

BECK, I.; JOCHNER, S.; GILLES, S.; MENZEL, A.; RING, J.; BEHRENDT, H.; SCHMIDT-WEBER, C.; TRAIDL-HOFFMANN, C. Influence of environmental factors on the allergenic potential of birch pollen. Allergy, Copenhagen, v. 67, p. 82-82, 2012. http:// dx.doi.org/10.1371/journal.pone.0080147.

BOYCE, J. A.; ASSA'AD, A.; BURKS, A. W.; JONES, S. M.; SAMPSON, H. A.; WOOD, R. A.; PLAUT, M.; COOPER, S. F.; FENTON, M. J.; ARSHAD, S. H.; BAHNA, S. L.; BECK, L. A.; BYRD-BREDBENNER, C.; CAMARGO, C. A. Jr; EICHENFIELD, L.; FURUTA, G. T.; HANIFIN, J. M.; JONES, C.; KRAFT, M.; LEVY, B. D.; LIEBERMAN, P.; LUCCIOLI, S.; MCCALL, K. M.; SCHNEIDER, L. C.; SIMON, R. A.; SIMONS, F. E.; TEACH, S. J.; YAWN, B. P.; SCHWANINGER, J. M. Guidelines for the diagnosis and management of food allergy in the united states: summary of the NIAID-sponsored expert panel report. The Journal of Allergy and Clinical Immunology, St. Louis, v. 126, n. 6, p. 1105-1118, 2010. http://dx.doi.org/10.1016/j.jaci.2010.10.008. PMid:21134568.

BUHRING, H. J.; STREBLE, A.; VALENT, P. The basophil-specific ectoenzyme E-NPP3 (CD203c) as a marker for cell activation and allergy diagnosis. International Archives of Allergy and Immunology, New York, v. 133, n. 4, p. 317-329, 2004. http:// dx.doi.org/10.1159/000077351. PMid:15031605.

BURKS, A. W.; TANG, M.; SICHERER, S.; MURARO, A.; EIGENMANN, P. A.; EBISAWA, M.; FIOCCHI, A.; CHIANG, W.; BEYER, K.; WOOD, R.; HOURIHANE, J.; JONES, S. M.; LACK, G.; SAMPSON, H. A. ICON: food allergy. The Journal of Allergy and Clinical Immunology, St. Louis, v. 129, n. 4, p. 906-920, 2012. http://dx.doi.org/10.1016/j.jaci.2012.02.001. PMid:22365653.

CAUBET, J.-C.; MASILAMANI, M.; RIVERS, N. A.; MAYER, L.; SAMPSON, H. A. Potential non-T cells source of interleukin-4 in food allergy. Pediatric Allergy and Immunology, Copenhagen, v. 25, n. 3, p. 243-249, 2014. http://dx.doi.org/10.1111/pai.12207. PMid:24576111.

CIANFERONI, A.; SPERGEL, J. M. Food allergy: review, classification and diagnosis. Allergology International, Carlton, v. 58, n. 4, p. 457-466, 2009. http://dx.doi.org/10.2332/allergolint.09-RAI-0138. PMid:19847094.

DU TOIT, G.; ROBERTS, G.; SAYRE, P. H.; BAHNSON, H. T.; RADULOVIC, S.; SANTOS, A. F.; BROUGH, H. A.; PHIPPARD, D.; BASTING, M.; FEENEY, M.; TURCANU, V.; SEVER, M. L.; 
LORENZO, M. G.; PLAUT, M.; LACK, G.; TEAM, L. S. Randomized trial of peanut consumption in infants at risk for peanut allergy. The New England Journal of Medicine, Boston, v. 372, n. 9 , p. 803-813, 2015. http://dx.doi.org/10.1056/NEJMoa1414850. PMid:25705822

DUPONT, C. Food allergy: recent advances in pathophysiology and diagnosis. Annals of Nutrition \& Metabolism, New York, v. 59, p. 8-18, 2011. Supplement 1. http://dx.doi.org/10.1159/000334145. PMid:22189252

FALCONE, F. H.; GIBBS, B. F. Purification of basophils from peripheral human blood. Methods in Molecular Biology, Clifton, v. 1192, p. 35-47, 2014. http://dx.doi.org/10.1007/978-1-49391173-8_2. PMid:25149481.

FEEHLEY, T.; NAGLER, C. R. Cellular and molecular pathways through which commensal bacteria modulate sensitization to dietary antigens. Current Opinion in Immunology, Philadelphia, v. 31, p. 79-86, 2014. http://dx.doi.org/10.1016/j.coi.2014.10.001. PMid:25458998.

FLEISCHER, D. M.; SICHERER, S.; GREENHAWT, M.; CAMPBELL, D.; CHAN, E.; MURARO, A.; HALKEN, S.; KATZ, Y.; EBISAWA, M.; EICHENFIELD, L.; SAMPSON, H.; LACK, G.; DU TOIT, G.; ROBERTS, G.; BAHNSON, H.; FEENEY, M.; HOURIHANE, J.; SPERGEL, J.; YOUNG, M.; AS'AAD, A.; ALLEN, K.; PRESCOTT, S.; KAPUR, S.; SAITO, H.; AGACHE, I.; AKDIS, C. A.; ARSHAD, H.; BEYER, K.; DUBOIS, A.; EIGENMANN, P.; FERNANDEZ-RIVAS, M.; GRIMSHAW, K.; HOFFMAN-SOMMERGRUBER, K.; HOST, A.; LAU, S.; O'MAHONY, L.; MILLS, C.; PAPADOPOULOS, N.; VENTER, C.; AGMON-LEVIN, N.; KESSEL, A.; ANTAYA, R.; DROLET, B.; ROSENWASSER, L. Consensus communication on early peanut introduction and the prevention of peanut allergy in high-risk infants. The Journal of Allergy and Clinical Immunology, St. Louis, v. 136, n. 2, p. 258-261, 2015. http://dx.doi.org/10.1016/j. jaci.2015.06.001. PMid:26100082.

FORSBERG, A.; ABRAHAMSSON, T. R.; BJORKSTEN, B.; JENMALM, M. C. Pre- and post-natal Lactobacillus reuteri supplementation decreases allergen responsiveness in infancy. Clinical and Experimental Allergy, Oxford, v. 43, n. 4, p. 434-442, 2013. http://dx.doi.org/10.1111/cea.12082. PMid:23517039.

GADERMAIER, G.; HAUSER, M.; EGGER, M.; FERRARA, R.; BRIZA, P.; SANTOS, K. S.; ZENNARO, D.; GIRBL, T.; ZUIDMEERJONGEJAN, L.; MARI, A.; FERREIRA, F. Sensitization prevalence, antibody cross-reactivity and immunogenic peptide profile of Api g 2, the non-specific lipid transfer protein 1 of celery. PLoS One, San Francisco, v. 6, n. 8, p. e24150, 2011. http://dx.doi. org/10.1371/journal.pone.0024150. PMid:21897872.

GEORAS, S. N.; REZAEE, F.; LERNER, L.; BECK, L. Dangerous allergens: why some allergens are bad actors. Current Allergy and Asthma Reports, Philadelphia, v. 10, n. 2, p. 92-98, 2010. http://dx.doi.org/10.1007/s11882-010-0090-6. PMid:20425500.
GIBBS, B. F.; FALCONE, F. H. Preface. Basophils and mast cells. Methods in Molecular Biology, Clifton, v. 1192, p. v-vi, 2014. http://dx.doi.org/10.1007/978-1-4939-1173-8. PMid:25289400.

GILLES, S.; MARIANI, V.; BRYCE, M.; MUELLER, M. J.; RING, J.; BEHRENDT, H.; JAKOB, T.; TRAIDL-HOFFMANN, C. Pollen allergens do not come alone: pollen associated lipid mediators (PALMS) shift the human immune systems towards a $\mathrm{T}(\mathrm{H}) 2$ dominated response. Allergy, Asthma, and Clinical Immunology, Hamilton, v. 5, n. 1, p. 3, 2009. http://dx.doi.org/10.1186/17101492-5-3. PMid:19946407

GILLES, S.; JACOBY, D.; BLUME, C.; MUELLER, M. J.; JAKOB, T.; BEHRENDT, H.; SCHAEKEL, K.; TRAIDL-HOFFMANN, C. Pollen-derived low-molecular weight factors inhibit 6-sulfo LacNAc plus dendritic cells' capacity to induce T-helper type 1 responses. Clinical and Experimental Allergy, Oxford, v. 40, n. 2, p. 269-278, 2010. http://dx.doi.org/10.1111/j.13652222.2009.03369.x. PMid:20210806.

HENNERSDORF, F.; FLORIAN, S.; JAKOB, A.; BAUMGARTNER, K.; SONNECK, K.; NORDHEIM, A.; BIEDERMANN, T.; VALENT, P.; BUHRING, H. J. Identification of CD13, CD107a, and CD164 as novel basophil-activation markers and dissection of two response patterns in time kinetics of IgE-dependent upregulation. Cell Research, Beijing, v. 15, n. 5, p. 325-335, 2005. http://dx.doi. org/10.1038/sj.cr.7290301. PMid:15916720.

HERRE, J.; GRÖNLUND, H.; BROOKS, H.; HOPKINS, L.; WAGGONER, L.; MURTON, B.; GANGLOFF, M.; OPALEYE, O.; CHILVERS, E. R.; FITZGERALD, K.; GAY, N.; MONIE, T.; BRYANT, C. Allergens as immunomodulatory proteins: the cat dander protein Fel d 1 enhances TLR activation by lipid ligands. Journal of Immunology, Baltimore, v. 191, n. 4, p. 1529-1535, 2013. http://dx.doi.org/10.4049/jimmunol.1300284. PMid:23878318.

HIRAGUN, M.; ISHII, K.; HIRAGUN, T.; SHINDO, H.; MIHARA, S.; MATSUO, H.; HIDE, M. The sensitivity and clinical course of patients with wheat-dependent exercise-induced anaphylaxis sensitized to hydrolyzed wheat protein in facial soap - secondary publication. Allergology International, Carlton, v. 62, n. 3, p. 351-358, 2013. http://dx.doi.org/10.2332/allergolint.13-OA-0553. PMid:23880617.

HOLLINGSWORTH, J. W.; MARUOKA, S.; BOON, K.; GARANTZIOTIS, S.; LI, Z.; TOMFOHR, J.; BAILEY, N.; POTTS, E. N.; WHITEHEAD, G.; BRASS, D. M.; SCHWARTZ, D. A. In utero supplementation with methyl donors enhances allergic airway disease in mice. The Journal of Clinical Investigation, New Haven, v. 118, n. 10, p. 3462-3469, 2008. PMid:18802477.

JYONOUCHI, S.; ABRAHAM, V.; ORANGE, J. S.; SPERGEL, J. M.; GOBER, L.; DUDEK, E.; SALTZMAN, R.; NICHOLS, K. E.; CIANFERONI, A. Invariant natural killer T cells from children with versus without food allergy exhibit differential responsiveness to milk-derived sphingomyelin. The Journal of Allergy and Clinical Immunology, St. Louis, v. 128, n. 1, p. 102-109, 2011. http://dx.doi.org/10.1016/j.jaci.2011.02.026. PMid:21458849. 
KANNY, G.; MONERET-VAUTRIN, D. A.; FLABBEE, J.; BEAUDOUIN, E.; MORISSET, M.; THEVENIN, F. Population study of food allergy in France. The Journal of Allergy and Clinical Immunology, St. Louis, v. 108, n. 1, p. 133-140, 2001. http://dx.doi.org/10.1067/ mai.2001.116427. PMid:11447395.

KAUFFMAN, H. F.; TAMM, M.; TIMMERMAN, J. A. B.; BORGER, $P$. House dust mite major allergens Der $p 1$ and Der $p 5$ activate human airway-derived epithelial cells by protease-dependent and protease-independent mechanisms. Clinical and Molecular Allergy, London, v. 4, p. 5-5, 2006. PMid:16569217.

KIM, J. S.; NOWAK-WEGRZYN, A.; SICHERER, S. H.; NOONE, S.; MOSHIER, E. L.; SAMPSON, H. A. Dietary baked milk accelerates the resolution of cow's milk allergy in children. The Journal of Allergy and Clinical Immunology, St. Louis, v. 128, n. 1, p. 125-131, 2011. http://dx.doi.org/10.1016/j.jaci.2011.04.036. PMid:21601913.

LEONARD, S. A.; SAMPSON, H. A.; SICHERER, S. H.; NOONE, S.; MOSHIER, E. L.; GODBOLD, J. and NOWAK-WEGRZYN, A. Dietary baked egg accelerates resolution of egg allergy in children. Journal of Allergy and Clinical Immunology, St. Louis, v. 130, n. 2, p. 473-480, 2012. http://dx.doi.org/10.1016/j. jaci.2012.06.006. PMID: 22846751

LIEBERMAN, J. A.; SICHERER, S. H. The diagnosis of food allergy. American Journal of Rhinology \& Allergy, Providence, v. 24, n. 6, p. 439-443, 2010. http://dx.doi.org/10.2500/ajra.2010.24.3515. PMid:21144222.

LIN, J.; RENAULT, N.; HAAS, H.; SCHRAMM, G.; VIETHS, S.; VOGEL, L.; FALCONE, F. H.; ALCOCER, M. J. C. A novel tool for the detection of allergic sensitization combining protein microarrays with human basophils. Clinical and Experimental Allergy, Oxford, v. 37, n. 12, p. 1854-1862, 2007. http://dx.doi. org/10.1111/j.1365-2222.2007.02803.x. PMid:18028099.

MADSEN, C. B.; HATTERSLEY, S.; BUCK, J.; GENDEL, S. M.; HOUBEN, G. F.; HOURIHANE, J. O. B.; MACKIE, A.; MILLS, E. N. C.; NORHEDE, P.; TAYLOR, S. L.; CREVEL, R. W. R. Approaches to risk assessment in food allergy: report from a workshop "developing a framework for assessing the risk from allergenic foods". Food and Chemical Toxicology, Oxford, v. 47, n. 2, p. 480-489, 2009. http://dx.doi.org/10.1016/j.fct.2008.12.001. PMid:19101602

METCALFE, D. D.; ASTWOOD, J. D.; TOWNSEND, R.; SAMPSON, H. A.; TAYLOR, S. L.; FUCHS, R. L. Assessment of the allergenic potential of foods derived from genetically engineered crop plants. Critical Reviews in Food Science and Nutrition, Boca Raton, v. 36, p. S165-186, 1996. Supplement. PMID: 8959382.

MIROTTI, L.; FLORSHEIM, E.; RUNDQVIST, L.; LARSSON, G.; SPINOZZI, F.; LEITE-DE-MORAES, M.; RUSSO, M.; ALCOCER, $M$. Lipids are required for the development of Brazil nut allergy: the role of mouse and human iNKT cells. Allergy, Copenhagen, v. 68, n. 1, p. 74-83, 2013. http://dx.doi.org/10.1111/all.12057. PMid:23137012.
NOVAK, N.; KRAFT, S.; BIEBER, T. IgE receptors. Current Opinion in Immunology, Philadelphia, v. 13, n. 6, p. 721-726, 2001. http:// dx.doi.org/10.1016/S0952-7915(01)00285-0. PMid:11677096.

OSBORNE, N. J.; UKOUMUNNE, O. C.; WAKE, M.; ALLEN, K. J. Prevalence of eczema and food allergy is associated with latitude in Australia. The Journal of Allergy and Clinical Immunology, St. Louis, v. 129, n. 3, p. 865-867, 2012. http://dx.doi.org/10.1016/j. jaci.2012.01.037. PMid:22305679.

PEI, B.; SPEAK, A. O.; SHEPHERD, D.; BUTTERS, T.; CERUNDOLO, V.; PLATT, F. M.; KRONENBERG, M. Diverse endogenous antigens for mouse NKT cells: self-antigens that are not glycosphingolipids. Journal of Immunology, Baltimore, v. 186, n. 3, p. 1348-1360, 2011. http://dx.doi.org/10.4049/jimmunol.1001008. PMid:21191069.

PRESCOTT, S.; ALLEN, K. J. Food allergy: riding the second wave of the allergy epidemic. Pediatric Allergy and Immunology, Copenhagen, v. 22, n. 2, p. 155-160, 2011. http://dx.doi. org/10.1111/j.1399-3038.2011.01145.x. PMid:21332796.

RHOST, S.; LOFBOM, L.; RYNMARK, B.-M.; PEI, B.; MANSSON, J.-E.; TENEBERG, S.; BLOMQVIST, M.; CARDELL, S. L. Identification of novel glycolipid ligands activating a sulfatide-reactive, CD1drestricted, type II natural killer T Iymphocyte. European Journal of Immunology, Weinheim, v. 42, n. 11, p. 2851-2860, 2012. http://dx.doi.org/10.1002/eji.201142350. PMid:22777932.

RIVAS, M. N; BURTON, O. T.; WISE, P.; ZHANG, Y. Q.; HOBSON, S. A.; GARCIA LLORET, M.; CHEHOUD, C.; KUCZYNSKI, J.; DESANTIS, T.; WARRINGTON, J.; HYDE, E. R.; PETROSINO, J. F.; GERBER, G. K.; BRY, L.; OETTGEN, H. C.; MAZMANIAN, S. K.; CHATILA, T. A. A microbiota signature associated with experimental food allergy promotes allergic sensitization and anaphylaxis. The Journal of Allergy and Clinical Immunology, St. Louis, v. 131, n. 1, p. 201-212, 2013. http://dx.doi.org/10.1016/j. jaci.2012.10.026. PMid:23201093.

RONA, R. J.; KEIL, T.; SUMMERS, C.; GISLASON, D.; ZUIDMEER, L.; SODERGREN, E.; SIGURDARDOTTIR, S. T.; LINDNER, T.; GOLDHAHN, K.; DAHLSTROM, J.; MCBRIDE, D.; MADSEN, C. The prevalence of food allergy: a meta-analysis. The Journal of Allergy and Clinical Immunology, St. Louis, v. 120, n. 3, p. 638-646, 2007. http://dx.doi.org/10.1016/j.jaci.2007.05.026. PMid:17628647.

ROUND, J. L.; MAZMANIAN, S. K. The gut microbiota shapes intestinal immune responses during health and disease. Nature Reviews. Immunology, London, v. 9, n. 5, p. 313-323, 2009. http://dx.doi.org/10.1038/nri2515. PMid:19343057.

SABATO, V.; BOITA, M.; SHUBBER, S.; BRIDTS, C. H.; SHIBUYA, A.; DE CLERCK, L. S.; FALCONE, F. H.; EBO, D. G. Mechanism of phosphatidylserine inhibition of IgE/Fc epsilon RI-dependent anaphylactic human basophil degranulation via CD300a. The Journal of Allergy and Clinical Immunology, St. Louis, v. 134, n. 3, p. 734-737, 2014. http://dx.doi.org/10.1016/j.jaci.2014.03.029. PMid:24815424. 
SANTOS, A. F.; DOUIRI, A.; BECARES, N.; WU, S.-Y.; STEPHENS, A.; RADULOVIC, S.; CHAN, S. M. H.; FOX, A. T.; DU TOIT, G.; TURCANU, V.; LACK, G. Basophil activation test discriminates between allergy and tolerance in peanut-sensitized children. The Journal of Allergy and Clinical Immunology, St. Louis, v. 134, n. 3, p. 645-652, 2014. http://dx.doi.org/10.1016/j.jaci.2014.04.039. PMid:25065721.

SANTOS, A. F.; DU TOIT, G.; DOUIRI, A.; RADULOVIC, S.; STEPHENS, A.; TURCANU, V.; LACK, G. Distinct parameters of the basophil activation test reflect the severity and threshold of allergic reactions to peanut. The Journal of Allergy and Clinical Immunology, St. Louis, v. 135, n. 1, p. 179-186, 2015. http:// dx.doi.org/10.1016/j.jaci.2014.09.001. PMid:25567046.

SASTRE, J. Molecular diagnosis in allergy. Clinical and Experimental Allergy, Oxford, v. 40, n. 10, p. 1442-1460, 2010. http://dx.doi. org/10.1111/j.1365-2222.2010.03585.x. PMid:20682003.

SHARIEF, S.; JARIWALA, S.; KUMAR, J.; MUNTNER, P.; MELAMED, M. L. Vitamin D levels and food and environmental allergies in the United States: results from the national health and nutrition examination survey 2005-2006. The Journal of Allergy and Clinical Immunology, St. Louis, v. 127, n. 5, p. 1195-1202, 2011. http://dx.doi.org/10.1016/j.jaci.2011.01.017. PMid:21329969.

SICHERER, S. H.; SAMPSON, H. A. Food allergy: epidemiology, pathogenesis, diagnosis, and treatment. Journal of Allergy and Clinical Immunology, St. Louis, v. 133,n. 2, p. 291-307, 2014. PMid:24388012. http://dx.doi.org/10.1016/j.jaci.2013.11.020. PMid:24388012.

SICHERER, S. H.; SAMPSON, H. A. Food allergy. The Journal of Allergy and Clinical Immunology, St. Louis, v. 125, n. 2, p. S116-S125, 2010. Supplement 2. http://dx.doi.org/10.1016/j. jaci.2009.08.028. PMid:20042231.

TORDESILLAS, L.; MONDOULET, L.; BENHAMOU, P. H.; SAMPSON, H. A.; BERIN, C. Epicutaneous but not oral immunotherapy induces antigen-specific gastrointestinal tregs and protects against food-induced anaphylaxis. The Journal of Allergy and Clinical Immunology, St. Louis, v. 135, n. 2, p. AB226-AB226, 2015. http://dx.doi.org/10.1016/j.jaci.2014.12.1674.

TROMPETTE, A.; DIVANOVIC, S.; VISINTIN, A.; BLANCHARD, C.; HEGDE, R. S.; MADAN, R.; THORNE, P. S.; WILLS-KARP, M.; GIOANNINI, T. L.; WEISS, J. P.; KARP, C. L. Allergenicity resulting from functional mimicry of a Toll-like receptor complex protein. Nature, London, v. 457, n. 7229, p. 585-588, 2009. http://dx. doi. org/10.1038/nature07548. PMid:19060881.

VOGEL, L.; HOLZHAUSER, T.; VIETHS, S. Development of a biological assay to determine the allergenic potential of foods. Journal für Verbraucherschutz und Lebensmittelsicherheit, New York, v. 1, n. 4, p. 317-324, 2006. http://dx.doi.org/10.1007/ s00003-006-0054-X.

WEISSE, K.; WINKLER, S.; HIRCHE, F.; HERBERTH, G.; HINZ, D.; BAUER, M.; ROEDER, S.; ROLLE-KAMPCZYK, U.; VON BERGEN, M.; OLEK, S.; SACK, U.; RICHTER, T.; DIEZ, U.; BORTE, M.; STANGL, G. I.; LEHMANN, I. Maternal and newborn vitamin D status and its impact on food allergy development in the German LINA cohort study. Allergy, Copenhagen, v. 68, n. 2, p. 220-228, 2013. http://dx.doi.org/10.1111/all.12081. PMid:23253182.

WORLD HEALTH ORGANIZATION - WHO; FOOD AND AGRICULTURE ORGANIZATION - FAO. Joint FAO/WHO expert consultation on foods derived from biotechnology. Rome: FAO, 2001. Available at: <http://www.fao.org/ag/agn/food/pdf/ bi03al.pdf>. Accessed on: 19 Apr. 2016.

ZUIDMEER, L.; GOLDHAHN, K.; RONA, R. J.; GISLASON, D.; MADSEN, C.; SUMMERS, C.; SODERGREN, E.; DAHLSTROM, J.; LINDNER, T.; SIGURDARDOTTIR, S. T.; MCBRIDE, D.; KEIL, T. The prevalence of plant food allergies: a systematic review. The Journal of Allergy and Clinical Immunology, St. Louis, v. 121, n. 5, p. 1210-1218, 2008. http://dx.doi.org/10.1016/j. jaci.2008.02.019. PMid:18378288. 